\title{
Implementation of OCR (Optical Character Recognition) Using Otsu Threshold Method for Detecting Tajweed Qur'an
}

\author{
Didit Meidi $^{1}$, Yana Aditia Gerhana ${ }^{2}$, Aldy Rialdy Atmadja ${ }^{3}$, Popon Dauni ${ }^{4}$ \\ \{1diditmeidi18@gmail.com, ${ }^{2}$ yanagerhana@uinsgd.ac.id, ${ }^{3}$ aldy@if.uinsgd.ac.id, \\ ${ }^{4}$ popon.dauni@uinsgd.ac.id\}
}

Department of Informatics, Faculty of Science and Technology $y^{1,2,3}$

\begin{abstract}
Qur'an is guidelines for Muslims. Appreciate and interpret the Qur'an requires knowledge and understanding. Reading the Qur'an should be tartil, tartil read here interpreted in accordance with the rules of recitation. The introduction of this recitation until now most still use traditional ways in which the method generally using the guidelines of the textbook or learn direct to those skilled in the field of Science recitation. Students as one of the subjects studied the Qur'an need to understand the Qur'an. In the middle of the development of technology and gadgets, allowing applications that can help in studying recitation. This study will discuss the application of recitation detection using OCR (Optical Character Recognition) and Threshold Otsu algorithm that can be read visually recitation by utilizing the camera features on the gadget. Applications Qur'an recitation detector that uses OCR and Otsu threshold algorithm with test data 200 Data obtained by percentage of $66.5 \%$.
\end{abstract}

Keywords: OCR, OTSU Threshold, Qur'an Application

\section{Introduction}

The Qur'an is the holy book of Muslims are obliged to believe and put into practice, to be able to practice it must be able to read the Qur'an. read the Qur'an is not the same as reading a book, there are rules that must be met to be able to read the Qur'an is with tartil. Tartil is smarten reading the letters of the Koran to light and regular, familiar places waqaf, in accordance with the rules of Tajweed and not in a hurry[1], However, not all Muslims to read the Qur'an with tartil. Especially outlined in this study are students.

This is evidenced by the results of a survey conducted by the author on 30 students at one of the colleges of Islam, there were $41.86 \%$ of the students who understand Tajweed and $44.65 \%$ of the students who apply Tajweed when reading the Qur'an. However, the introduction of this recitation until now most still use traditional ways in which the method generally using the guidelines of the textbook or learn langusng to those skilled in the Field of Science recitation. Meanwhile, gadget or smartphone development has been rapid. As we know, the gadget is a contemporary means to search for educational material or information. So that now requires students to learn to understand the application for recitation. It is based on a survey to obtain data for 91. 
The gadget itself has a camera function to take a picture or photograph. By leveraging the capabilities of the gadget is capable of taking pictures. Thus, it takes OCR application that uses Threshold and use the Otsu algorithm. OCR (Optical Character Recognition) or often referred to Pattern Recognition character is one branch of pattern recognition. OCR Represents One method of pattern recognition of numbers or letters that are widely used Backpropagation Neural Network algorithm, the system works like a human brain to recognize patterns after training or checks on some sample beforehand[2], With this, the OCR method can be used to recognize patterns of characters that can be implemented into the introduction of Science Tajweed and recitation detect capture process. This research resulted in detection applications make use of the method of recitation ocr and Otsu threshold algorithm.

There are several previous studies of trends in this study was also conducted one of which is the research done Luszara Lucky Viona et al, in a study to determine the sentence tajwid used algorithm method light stemming, Stemming is one of the techniques used in Natural Language Processing / Natural Language Processing (NLP) to restore the shape of a sentence into its root form and need not be in accordance with the syntax on the science of recitation. By using this method we will get the base and affix sentence contained in the sentence, so that it can determine the type of sentence[3],

Research conducted by Sanjaya Anggi Kusnanto, which make the detection of the drug and food using OCR (Optical Character Recognition) or often called string matching algorithm that is used to convert the image into a character shaped in the form of text characters. Results character of these processes were combined to create a string. In the process of the conversion algorithm, called Neural Network Backpropagation where the algorithm can determine which approach the character output pattern of the character image is entered[2],

Research conducted by Ikmal Farih $M$. et al, in these studies is the puppet image segmentation with Otsu method. His research aims to make the younger generation more mngenal puppet as part of the cultural heritage of their ancestors and to preserve the culture of Indonesia, especially the puppets. In this case the required preservation of Wayang Kulit with developing an interesting and educational media, one of the important processes in developing media is segmentation[4],

\section{Methodology}

\subsection{Problem analysis}

Analysis of this issue is about how to implement an OCR (Optical Character Recognition) into learning the science of recitation, which aims to detect the recitation of the Qur'an for student learning.

The following is a general description of learning recitation is done at this point:

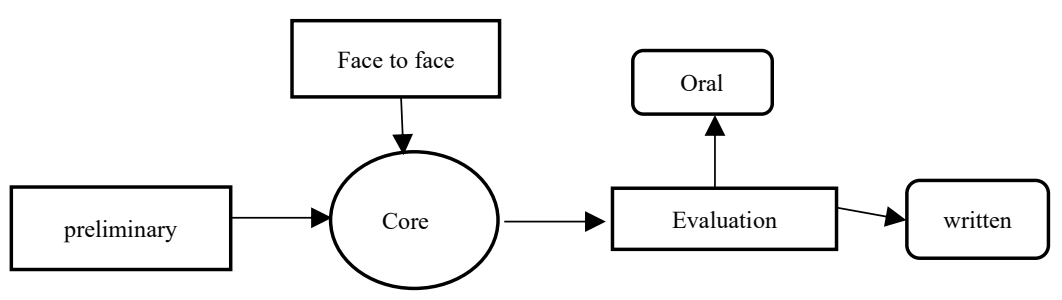


Fig. 1 Program Analysis

\section{A. Research data}

To run the system takes data as a reference to conversion. Namely, paragraph or sentence in the Qur'an which contains recitation. Paragraph or sentence in the Qur'an in the conversion into text that contains information recitation. Then recitation used in this system is a four-law, the law of the dead nun and tanwin, ta'rief lam, mim dead, and lam further inside. As for the dead nun law and tanwin divided into five, namely; idzhar, idgham bigunnah, idgham bilagunnah, iqlab, and ikhfa haqiqi. Then further on the lam ta'rif law is divided into two parts, the solar lam and alif alif lam Qomariah. Furthermore, the law meme die which is divided into three parts, idzhar syafawi, ikhfa syafawi, idgham mimi. Recently, the law lam jalalah, for lam jalalah law is divided into two parts, namely lam jalalah tafkhim and lam jalalah tarqiq,

Here is an example sentence containing four recitation, namely;

1. Law nun die and tanwin

Below are 20 examples of the Dead Nun law and Tanwin consisting of idzhar, idgham bighunnah, idgham bilagunnah, iqlab, and ikhfa haqiqi.

Table 1 Dead nun lam and tanwim

\begin{tabular}{|c|c|c|c|c|c|}
\hline No. & Idzhar & $\begin{array}{c}\text { Idgham } \\
\text { Bighunnah }\end{array}$ & $\begin{array}{c}\text { Idgham } \\
\text { Bilagunnah }\end{array}$ & Iqlab & Ikhfa haqiqi \\
\hline 1. & من ا جر & فمن يعمل & من لم & من بعد & من تلق \\
\hline 2. & و منهم & ان نفعت & من ربكم & من بين & عند ه \\
\hline 3. & من حد & من منع & من لدنك & بذ نبهم & من طين \\
\hline 4. & من خفت & من ولي & من رسول & انبتكم & من قبل \\
\hline 5. & من علق & ومن ييتغ & من لد نآ & انبياً & من كم \\
\hline 6. & من غل & من نصر & من ربهم & ينبغي & من ثقلت \\
\hline 7. & منه & لن يضر & وان لم تؤ & من بعثن & من جوع \\
\hline 8. & عنهم & من نفس & من لعنه & تتبت & من زكها \\
\hline 9. & من خير & ومن يطع & من ربك & من بقلها & فانذر \\
\hline 10. & من اله & ومن يعص & من ربي & عن بعد & من سجيل \\
\hline 11. & من اهل & من يفعل & من ربه" & بذنبه & من شر \\
\hline 12. & من امن & من يكن & من رب & من بينتا & عن صلا \\
\hline 13. & وتنهون & عن موا & من رزقه & جنب & من ضر \\
\hline 14. & ان خفتم & ان يشر ك & فمن ربكما & من بخل & ينظرون \\
\hline 15. & من خلفهم & من يلعن & ان لن & اذانبعث & انفسكم \\
\hline 16. & منهما & ان يتحا & من لو & لينبد ن & انزل \\
\hline 17. & ان ارد & ان يكفر & فمن ربكما & من بأس & عندر \\
\hline 18. & منهن & ان يضلهح & من لا يسئلكم & لذنبك & لن تغني \\
\hline 19. & تنهو ن & كن معهم & ان لا & فأنبتن & من ذلكم \\
\hline 20. & ان خفتم & من يقاتل & ان راه & و انبتنا & ان ثو \\
\hline
\end{tabular}


2. Lam Ta'rif law

Below are 20 examples Lam Ta'rief law comprising alif lam syamsiyah and alif lam Qomariyah.

Table 2 Lam ta'rief law

\begin{tabular}{|c|c|c|}
\hline No. & Alif Lam Syamsiyah & Alif Lam Qomariah \\
\hline 1. & الطارق & فى الارض \\
\hline 2. & الثلث & البر \\
\hline 3. & السمك & الغفور \\
\hline 4. & الرحمن & و والحب \\
\hline 5 & التين & من الجنة \\
\hline 6. & الزكوة & الكتب \\
\hline 7. & الذكر & الولدان \\
\hline 8. & الصلحت & الخير \\
\hline 9. & النور & الفاتحة \\
\hline 10. & الدين & فى العقد \\
\hline 11. & الثمس & القمر \\
\hline 12. & الظلمت & اليتيم \\
\hline 13. & الضحى & الموت \\
\hline 14. & اللسان & الهذى \\
\hline 15. & الرحيم & البرق \\
\hline 16. & الصر اط & الحي \\
\hline 17. & الصلوة & العزيز \\
\hline 18. & السفهاً & الحكيم \\
\hline 19. & الضللة & الفتنة \\
\hline 20. & الناس & العلم \\
\hline
\end{tabular}

\section{Mim Law Dead}

Below are 20 examples of the Dead Mim law consisting of idzhar syafawi, ikhfa syafawi, and idgham mimi.

Table 3 Table mim dead law

\begin{tabular}{|c|c|c|c|}
\hline No. & Idzhar Syafawi & Ikhfa Syafawi & Mimi Idgham \\
\hline 1. & لكم اموا & هم بغير & لهم من \\
\hline 2. & عمت & هم بخر & كم من \\
\hline 3. & لهم جنت & بهم بذ & هم مهتدون \\
\hline 4. & مكم سبا & هم بدء & لهم ما \\
\hline 5. & الم نجعل & ميهم بحجا & لهم مغفر \\
\hline 6. & لكم اية & يعلم بأن & لكم من \\
\hline 7. & لهم و حسن & هم بآيا & هم من \\
\hline 8. & هم ن ائمون & هم به & يكم من \\
\hline 9. & لم يلد & هم بر & فكم ملك \\
\hline 10. & لم يولد & ام بعد & لهم مثنلا \\
\hline 11. & لم يكن & هم باذن & كم معكم \\
\hline
\end{tabular}




\begin{tabular}{|c|c|c|c|}
\hline 12. & فلم يجد & هم بعذاب & هم مظلمون \\
\hline 13. & هم ام لم & كلبهم با سط & هم مكر \\
\hline 14. & هم اجر & نكم برزق & لهم مما \\
\hline 15. & كم ازو & عليهم بنيا & جكم من \\
\hline 16. & الم تر & ربهم با & بهم مرض \\
\hline 17. & هم باذن & هم بما & ئكم معر \\
\hline 18. & الم نجعل & هم بلقاء & قببلهم من \\
\hline 19. & علمت & هم ببطن & غشيهم مو \\
\hline 20. & هم فهم & ئكم با & اتهم من \\
\hline
\end{tabular}

B. Calculation Otsu Threshold

Here is a step calculation using Otsu algorithm method:

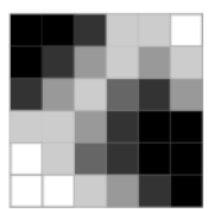

Fig. 2 The image that has been converted to grayscale

1. Grayscaling

If there is an image with a length of 6 pixels and a width of 6 pixels, then the calculation process grayscaling is to perform the calculations in order to produce new RGB values for each pixel input image.

Grayscaling $=5.6 g(i, j)=\frac{8+7+2}{3}$

2. process Histogram

After grayscaling process, then the calculation of the RGB values and histogram for each pixel, with the following steps:

If the histogram will be calculated as a combination of pixel length and width of the image

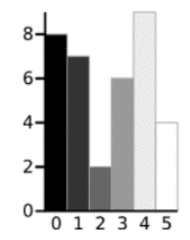

Fig. 3 Histogram graph clustering foreground and background

Here is a picture of the background histogram graph that has been separated from the foreground. 


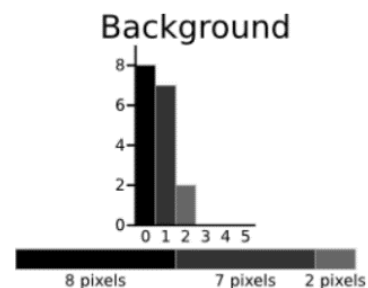

Fig. 4 Histogram graph background

Here is a picture of the foreground histogram graph that has been separated from the background.

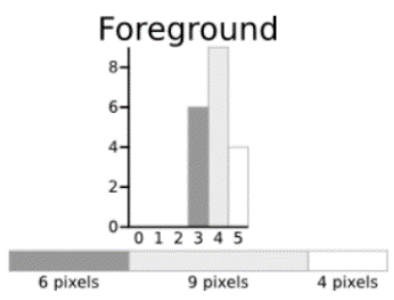

Fig. 5 Histogram graph foreground

3. Otsu Tresholding Method process

The first process is the calculation seek variance background. Can be seen in the following calculation:

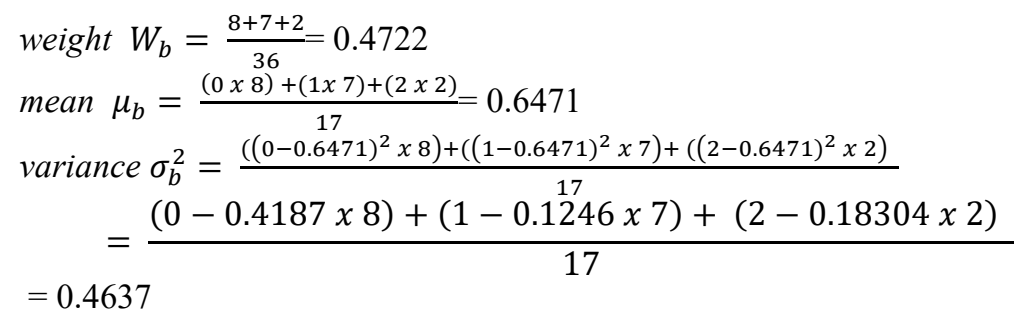

The first process is the calculation of variance foreground looking. Can be seen in the following calculation:

$$
\begin{aligned}
& \text { weight }=0.5278 W_{f}=\frac{6+9+4}{36} \\
& \text { mean }=3.8947 \mu_{f}=\frac{(3 \times 6)+(4 \times 9)+(5 \times 4)}{19} \\
& \text { variance } \sigma_{f}^{2}=\frac{\left((3-3.8947)^{2} \times 6\right)+\left((4-3.8947)^{2} \times 9\right)+\left((5-3.8947)^{2} \times 4\right)}{19} \\
& \qquad=\frac{(4.8033 \times 6)+(0.0997 \times 9)+(4.8864 \times 4)}{19} \\
& =0.5152
\end{aligned}
$$


4. Pixel Value Determination Process After Otsu

To find a threshold value of an object of comparison of background and foreground, by finding the lowest threshold value in order to clarify the foreground and background objects to be identified clearly then be calculated as follows:

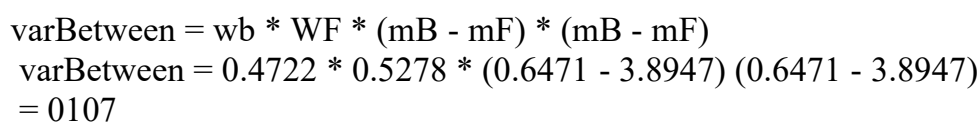

\section{Result and Discussion}

\subsection{Image Processing Testing}

After a successful input image in the input and translate button on tap, eating preprocessing system will run a process that begins with a grayscale process continue with the process Tresholding with Otsu method. The process of the first run is grayscaling process input images, each pixel RGB values of the input image will be taken and in doing calculations to make the ideal input into all-gray color. Illustration grayscaling calculation process can be seen in the table below.

Table 4 Illustration of the calculation process grayscaling

\begin{tabular}{llllll}
\hline Position & \multicolumn{3}{c}{ imagery } & Gs $=(0.21 \times 0.71 \times \mathrm{R}+\mathrm{G}+$ \\
\cline { 2 - 5 } & $\mathrm{R}$ & $\mathrm{G}$ & $\mathrm{B}$ & 0.07 & \\
\hline Pixel (1,1) & 244 & 11 & 11 & 59.82 \\
Pixel (1,1) & 244 & 11 & 11 & 59.82 \\
Pixel (1,1) & 244 & 11 & 11 & 59.82 \\
Pixel (1,1) & 244 & 11 & 11 & 59.82 \\
Pixel (1,1) & 244 & 11 & 11 & 59.82 \\
& & & & \\
& & & & \\
Pixel (200.196) & 244 & 11 & 11 & 59.82 \\
Pixel (200.197) & 244 & 11 & 11 & 59.82 \\
Pixel (200.198) & 244 & 11 & 11 & 59.82 \\
Pixel (200.199) & 244 & 11 & 11 & 59.82 \\
Pixel (200.200) & 244 & 11 & 11 & 59.82 \\
\hline
\end{tabular}

Each pixel of the input image taken its RGB value, then each of its RGB values at times with a certain value and is added to produce a new RGB values. From the results of the new RGB values later in the form of a new image-gray with RGB values and the new alpha.

The next process is the process of Otsu thresholding method, first find the value of the histogram of the input image. After the count value and the RGB histogram of the image to get the value threshold that is required. 


\subsection{Testing String Matching}

After the process of recognition by OCR Tesseract engine is completed, string recognition results will be interpreted and meaning obtained will be taken by the system then in doing the process of matching strings with data stored in a database which will result from the string matching that will generate information tajwid be displayed interface system, In this test done three tests, testing the brightness of the color of the writing, testing using writing and background to the brightness of different colors, testing on handwriting, and testing the accuracy of string matching with black colored paper and white background.

1. Testing with the brightness of the text color.

Here is a table of testing with color brightness level posts:

Table 5 Testing with color brightness level posts

\begin{tabular}{lcc}
\hline \multicolumn{1}{c}{ Color } & Detected & Not \\
\hline $\begin{array}{l}\text { Brightness } 40 \% \text { down } \\
\text { Brightness } 40 \% \text { and } \\
\text { above }\end{array}$ & $\checkmark$ & $\checkmark$ \\
\hline
\end{tabular}

Testing with the words that used color with a brightness of $40 \%$ down can be detected. Conversely, with the words that used color with a brightness of $40 \%$ or more is not detected. The conclusion of any color as long as its brightness $40 \%$ down, Otsu threshold algorithm and OCR (Optical Character Recognition) can still be detected.

2. Tests using text and background colors with different brightness levels.

The table below shows the results of a written test and background to the brightness of different colors:

Table 6 Tests using text and background colors with different brightness levels

\begin{tabular}{lccc}
\hline \multicolumn{2}{c}{ Color brightness } & \multicolumn{2}{c}{ result } \\
\hline writing & background & Detected & Not \\
\hline $\begin{array}{l}40 \% \text { and } \\
\text { above }\end{array}$ & $40 \%$ down & $\checkmark$ & \\
$40 \%$ down & $40 \%$ and above & $\checkmark$ & \\
$40 \%$ and & $40 \%$ and above & & $\checkmark$ \\
above & & & $\checkmark$ \\
$40 \%$ down & $40 \%$ down & & $\checkmark$ \\
\hline
\end{tabular}

This testing when using paper with a brightness of $40 \%$ or more and $40 \%$ background brightness down can still be detected, then to writing with a brightness of $40 \%$ down and the background with the brightness of $40 \%$ or more can still be detected. Furthermore, if the text with $40 \%$ and above color brightness and background with color brightness $40 \%$ above the result is not detected, then the brightness of the color of the writing of $40 \%$ down and $40 \%$ brightness of the background color undetected down the same result. So it can be 
concluded any background color and brightness as long as the different writings Otsu threshold algorithm and OCR (Optical Character Recognition) can still be detected.

\section{Tests on handwriting.}

Tests on the handwriting is hard, of all the data tested was not detected none, while the detected data from input to output does not match and his testimony was not appropriate. Can concluded for Otsu threshold algorithm and OCR (Optical Character Recognition) is still not perfect for detecting handwriting.

4. Testing accuracy of string matching with black colored paper and white background. Here is a graph of the results of matching strings:

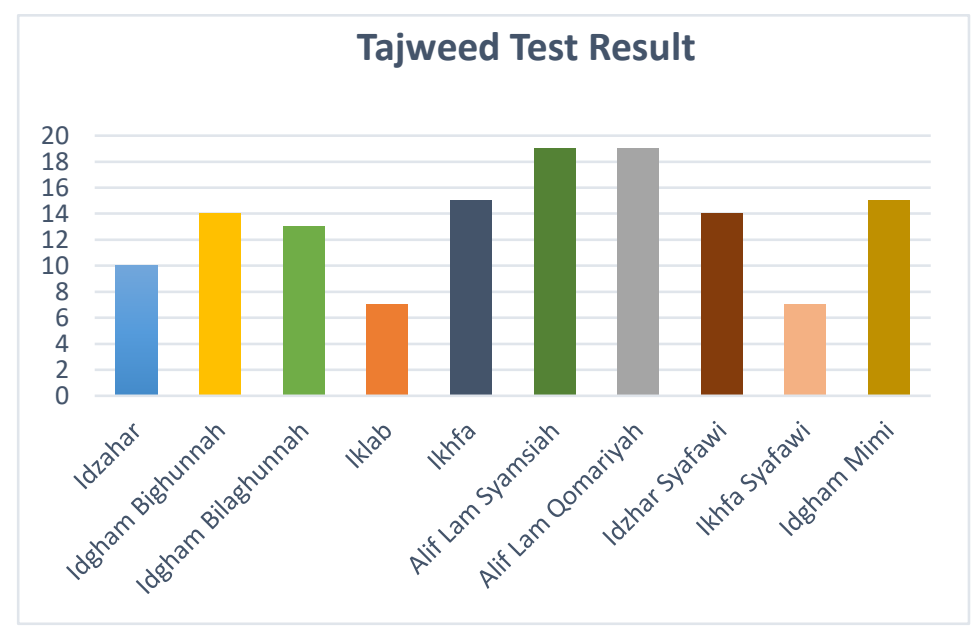

Fig. 6 String test result graph matching

The accuracy of the test results of the program, tested 200 data from three recitation which is divided into 10 types, the highest accuracy is lam ta'rif law, namely alif lam syamsiyah and Qomariyah. This is due to not having the same letter with other laws and does not contain two or more legal in every sentence. While most low accuracy is iklab and ikhfa syafawi law. This is because at every sentence is characterized by the same letter, and contain two or more laws. The few examples that are not readable at all it was because at the time of extraction is not perfect. Here are the results of reading accuracy percentage of recitation:

$$
\begin{aligned}
& =\frac{\text { valid amount of data }}{\text { total data }} \times 100 \% \\
& =\frac{133}{200} \times 100 \% \\
& =66,5 \%
\end{aligned}
$$

From the above calculation results obtained testing program accuracy of $66.5 \%$. Where are counted here is the number of valid data from the results of the testing string as many as 133 data. Then, the test data string as many as 133 data is divided by the number 
of overall data, the overall amount of data obtained from a total of data tajwid tested as many as 200 entries, then divided by $100 \%$, and a yield of $66.5 \%$.

\section{Conclusion}

Successfully apply OCR and Otsu threshold algorithm on detection applications recitation of the Qur'an by utilizing the Image Process and Tesseract OCR Engine for recitation reading system which is then converted into an image. But not all sentences can be read by OCR, it is influenced by the quality of the camera is not good, bad lighting, the density of words with each other, clarity of text, images, and phrases containing two law or more and sentences in the Qur 'an digital.

Based on the results of testing the accuracy of detecting application performance recitation of the Qur'an uses OCR and Otsu threshold algorithm with test data 200 Data obtained by percentage of $66.5 \%$, this is because at every sentence is characterized by the same letter, and contain two legal or more. The few examples that are not readable at all it was because at the time of extraction is not perfect. it could be inferred that the OCR and Otsu threshold accurate enough to detect the recitation of the Qur'an.

\section{References}

[1] Hadi, "Sistem Pakar untuk Mengidentifikasi Bacaan Tajwid di Al-Qur'an," pp. 1-12, 2011.

[2] A. S. Kusnanto, "Implementasi ( Optical Character Recognition ) Menggunakan Metode String Matching untuk Mendeteksi Obat dan Makanan,” J. Ilm. Komput. dan Inform. (KOMPUTA), ISSN 2089-9033, 2014.

[3] L. L. Viona, Y. Dwi, R. S. St, M. Kom, M. R. Pratama, and S. Kom, "Sistem Pendeteksi Ilmu Tajwid pada Al-Qur'an Menggunakan Algoritma Light Stemming," 1991.

[4] M. M. M. Ikmal Farih, Lukman Hakim, "Segmentasi Citra Wayang dengan Metode Otsu," CYBER-TECHN, vol. 11, no. 01, pp. 8-18, 2016. 